\title{
Asupan Kalsium dan Fosfor Berkaitan dengan Karies Gigi pada Anak Sekolah
}

\author{
Amilia Yuni Damayanti ${ }^{1}$, Joyeti Darni ${ }^{2}$, Ruskiah Octavia ${ }^{3}$ \\ ${ }^{1,2,3}$ Program Studi Ilmu Gizi, Universitas Darussalam Gontor, Ponorogo, Indonesia \\ Email:amilia@unida.gontor.ac.id
}

\begin{abstract}
This study aims to determine the relationship between calcium and phosphorus intake with dental caries of school children. This study was an observational study with a cross sectional design. The sampling technique used purposive sampling, with a total sample of 96 subjects. This research was conducted in Madrasah Ibtidaiyah Nurussalam, Ngawi starting from April - May 2019. Data on dental caries status (DMF-T index) was obtained by dental examination by a dentist. Data on calcium and phosphorus intake were obtained by direct interviews regarding the amount and type of intake using the Semi-Quantitative Food frequency Quesionaire (SQFFQ) form and the 24 hour food recall form. Calcium and phosphorus data were processed using Nutrisurvey software and the Indonesian Food Composition Table (TKPI). Chisquare statistical tests were used to analyze the relationship between calcium and phosphorus intake and dental caries. The majority of MI students who experience caries are aged 10 and 11 years. Calcium and phosphorus intake of subjects was classified as inadequate $(77,1 \%$ and 59,4\%). There was a significant relationship between calcium intake with dental caries $p=0,031(<0,05)$ and phosphorus intake with dental caries $p=0,029(<0,05)$. Adequate intake of calcium and phosphorus can reduce the risk of dental caries in children.
\end{abstract}

Keyword: Calcium, caries, intake, phosphorus

\begin{abstract}
Abstrak
Penelitian ini bertujuan untuk mengetahui hubungan antara asupan kalsium dan fosfor dengan karies gigi anak sekolah. Penelitian ini adalah penelitian observasional dengan desain cross sectional. Tehnik pengambilan sampel menggunakan purposive sampling, dengan jumlah sample sebanyak 96 subjek. Penelitian ini dilakukan di Madrasah Ibtidaiyah Nurussalam, Ngawi mulai dari bulan April - Mei 2019. Data status karies gigi (indeks DMF-T) diperoleh dengan melakukan pemeriksaan gigi oleh dokter gigi. Data asupan kalsium dan fosfor diperoleh dengan wawancara langsung mengenai jumlah dan jenis asupan menggunakan form Semi-Quantitative Food frequency Quesionaire (SQFFQ) dan form food recall 24 hours. Data kalsium dan fosfor diolah menggunakan software Nutrisurvey dan Tabel Komposisi Pangan Indonesia (TKPI). Uji statistik Chi-square digunakan untuk menganalisis hubungan anatar asupan kalsium dan fosfor dengan karies gigi. Mayoritas Siswa MI yang mengalami karies adalah usia 10 dan 11 tahun. Asupan kalsium dan fosfor subjek masih tergolong kurang (77,1\% dan 59,4\%). Terdapat hubungan yang signifikan antara asupan kalsium dengan karies gigi $\mathrm{p}=0,031(<0,05)$ dan asupan fosfor dengan karies gigi $\mathrm{p}=0,029(<0,05)$. Asupan kalsium dan fosfor yang cukup dapat menurunkan resiko karies gigi pada anak.
\end{abstract}

Kata Kunci: Kalsium, karies, asupan, fosfor 


\section{PENDAHULUAN}

Karies gigi merupakan penyakit kronik dengan prevalensi tertinggi pada anak usia sekolah. Anak usia sekolah dasar cenderung memiliki prevalensi karies gigi yang lebih tinggi dibandingkan dengan usia anak pra sekolah yaitu 50,5\% dan 21,4\% (Fleming and Afful, 2018). Prevalensi nasional masalah gigi dan mulut adalah 25,9 $\%$, sebanyak 14 provinsi mempunyai prevalensi masalah gigi dan mulut diatas angka nasional (Kemenkes RI, 2018).

Indikator yang digunakan di Indonesia untuk menilai tingkat keparahan kerusakan gigi yaitu Indeks DMF-T. Indeks DMF-T merupakan penjumlahan dari komponen D-T, M-T, dan F-T yang menunjukkan banyaknya kerusakan gigi yang pernah dialami seseorang, baik berupa Decay/D (merupakan jumlah gigi permanen yang mengalami karies dan belum diobati atau ditambal), Missing/M (jumlah gigi permanen yang dicabut atau masih berupa sisa akar), dan Filling/F adalah jumlah gigi permanen yang telah dilakukan penumpatan atau ditambal (Kementrian Kesehatan RI, 2018). Prevalensi nasional Indeks DMF-T adalah 4,6. Sebanyak 15 provinsi memiliki prevalensi di atas prevalensi nasional, salah satunya yaitu provinsi Jawa Timur (Kemenkes RI, 2013).

Karies gigi adalah penyakit gigi di mana metabolit asam organik menyebabkan demineralisasi enamel gigi secara bertahap, diikuti oleh destruksi proteolitik yang cepat pada struktur gigi. Karies dapat terjadi pada permukaan gigi mana saja. Penyebab karies gigi melibatkan banyak faktor. Empat faktor harus ada secara bersamaan yaitu host, mikroorganisme, karbohidrat yang dapat difermentasi dalam makanan, dan waktu (durasi) di mulut (Collins, Walsh and Figures, 1999). Bakteri untuk memetabolisme karbohidrat yang difermentasi, menghasilkan asam, dan menyebabkan penurunan $\mathrm{pH}$ saliva menjadi kurang dari 5,5. Setelah $\mathrm{pH}$ bersifat asam, yang dapat terjadi dalam beberapa menit, bakteri oral dapat memulai proses demineralisasi (Mahan and Raymond, 2017). Karies gigi dapat menyebabkan gangguan makan, hal ini dapat memberikan dampak jangka panjang pada anak seperti anemia defisiensi besi bahkan malnutrisi (Bener et al., 2013).

Berbagai masalah gigi-mulut pada anak seperi karies gigi dapat dicegah dengan pola asupan gizi yang tepat. Beberapa studi menunjukkan bahwa zat gizi merupakan salah satu komponen penting terhadap kesehatan gigi. Konsumsi makanan tinggi kalsium dan fosfor bermanfaat untuk mencegah karies gigi (Hendarto, 2015). Kekurangan mineral kalsium dan fosfor dilaporkan menyebabkan hipoplasia enamel dan meningkatkan resiko karies gigi (Mahan and Raymond, 2017). Ravishankar et al. (2012) menyatakan bahwa makanan sumber kalsium dan fosfor seperti produk susu akan membantu melindungi $\mathrm{pH}$ yang dihasilkan oleh makanan kariogenik, sehingga berpotensi mencegah terjadinya karies gigi (Ravishankar et al., 2012). Laporan pada studi lain juga menunjukkan bahwa asupan kalsium dan fosfor 
berpengaruh terhadap kesehatan gigi dan kejadian karies gigi pada anak sekolah. (Shita and Sulistiyani, 2010; Bener et al., 2013). Meskipun demikian, ada studi lain yang menyatakan bahwa tidak ada hubungan antara asupan kalsium dari makanan dan minuman dengan karies gigi (Meikawati, Sayono and Nurullita, 2005). Oleh karena itu, penelitian ini bertujuan untuk mengetahui hubungan antara asupan kalsium dan fosfor dengan karies gigi anak sekolah dasar.

\section{METODE}

\section{Desain, Tempat, dan Waktu}

Penelitian ini adalah penelitian observasional dengan desain cross sectional. Penelitian ini dilakukan di Madrasah Ibtidaiyah Nurussalam, Ngawi. Penelitian ini dilakukan mulai dari bulan April - Mei 2019. Variabel bebas dalam penelitian adalah asupan kalsium dan fosfor, sedangkan variabel terikat adalah karies gigi.

\section{Populasi dan Subyek Penelitian}

Populasi target dalam penelitian ini adalah anak sekolah dasar. Teknik pengambilan sampel menggunakan purposive sampling, dengan jumlah sampel sebanyak 96 subjek anak sekolah dasar MI Nurussalam di Ngawi dengan kriteria inklusi adalah anak sekolah dasar usia 7 - 12 tahun. Di dalam penelitian ini, kriteria eksklusinya yaitu anak sekolah dasar yang tidak bersedia mengisi kuesioner.

\section{Jenis dan Cara Pengambilan Data}

Data status karies gigi (indeks DMF-T) diperoleh dengan melakukan pemeriksaan gigi oleh dokter gigi. Alat dan instrument yang digunakan untuk mendeteksi karies gigi adalah alat diagnosa kedokteran gigi seperti kaca mulut, pinset, masker dan sarung tangan, alkohol 70\%, kapas, dan lembar pemeriksaan DMF-T. Data asupan kalsium dan fosfor diperoleh dengan wawancara langsung dengan anak SD (face to face/one-one) mengenai jumlah dan jenis asupan menggunakan SQ-FFQ. Pewawancara merupakan mahasiswa Prodi Ilmu Gizi semester akhir yang telah mendapat pelatihan mengenai dietary assessment. Data asupan kalsium dan fosfor didapatkan dengan SQ-FFQ yang dilakukan sebanyak satu kali pengambilan data. Bahan makanan yang tercantum dalam SQ-FFQ merupakan hasil pengembangan sendiri berdasarkan pangan lokal dan pengamatan di sekolah. Jumlah bahan makanan dalam SQ-FFQ yang digunakan adalah sebanyak 153 item yang terdiri dari makanan pokok, lauk hewani, lauk nabati, sayuran, buah-buahan dan serba-serbi. Penentuan porsinya bedasarkan Ukuran Rumah Tangga (URT). Kemudian dinyatakan dalam bentuk frekuensi (harian, mingguan dan bulanan). Data sekunder yang dikumpulkan adalah jenis kelamin dan data tanggal bulan tahun kelahiran. 


\section{Pengolahan dan Analisis Data}

Klasifikasi tingkat keparahan karies gigi dikategorikan menjadi tiga katagori, yaitu tingkat keparahan rendah dengan nilai DMF-T sebesar 0,0 - 2,6. Tingkat keparahan sedang dengan nilai DMF-T sebesar 2,7 - 4,4. Tingkat keparahan tinggi dengan nilai DMF-T sebesar $\geq 4,5$. (Kementrian Kesehatan RI, 2018). Data asupan makanan dikonversikan dalam bentuk gram untuk selanjutkan diproses menggunakan software Nutrisurvey 2007 dan Tabel Komposisi Pangan Indonesia (TKPI) (Kemenkes, 2017). Data asupan yang telah didapat kemudian dibandikan dengan AKG. Klasifikasi asupan kalsium dan fosfor terdiri dua kategori, yaitu Kurang (jika asupan $<80 \%$ dari AKG) dan Cukup (jika asupan $\geq 80-110 \%$ dari AKG) (Kementrian Kesehatan RI, 2019).

Uji statistik dimulai dengan uji Shaphiro-Wilk untuk mengetahui distribusi data. Data dikatakan normal jika mempunyai $\mathrm{p}>0,05$. Uji Chi-square digunakan untuk menganalisis hubungan antara asupan kalsium dan fosfor dengan karies gigi. Penelitian ini telah mendapat izin etik dari Komisi Etik Penelitian Kesehatan, RSUD Dr. Moewardi Fakultas Kedokteran Universitas Sebelas Maret dengan Nomor: 393/III/HREC/2019. Informed consent sudah didapatkan dari Guru dan Wali Murid.

\section{HASIL DAN PEMBAHASAN}

Jumlah Siswa MI yang mengalami karies gigi saat pemeriksaan menjadi subyek penelitian sebanyak 96 orang, diambil pada bulan April-Mei 2019. Klasifikasi tingkat keparahan karies gigi pada usia 12 tahun atau lebih dikategorikan menjadi lima katagori, yaitu tingkat keparahan rendah dengan nilai DMF-T sebesar 0,0 - 2,6. Tingkat keparahan sedang dengan nilai DMF-T sebesar 2,7 - 4,4. Tingkat keparahan tinggi dengan nilai DMF-T sebesar $\geq 4,5$.

Tabel 1. Karakteristik responden

\begin{tabular}{lcc}
\hline Variabel & Jumlah & Presentase \\
\hline Jenis Kelamin & 37 & $38,5 \%$ \\
Laki-laki & 59 & $61,5 \%$ \\
Perempuan & & \\
Usia & 1 & $1,1 \%$ \\
9 tahun & 36 & $37,5 \%$ \\
10 tahun & 41 & $42,7 \%$ \\
11 tahun & 18 & $18,7 \%$ \\
12 tahun & & \\
Status Karies & 13 & $13,6 \%$ \\
Rendah & 27 & $28,1 \%$ \\
Sedang & 56 & $58,3 \%$ \\
Tinggi & & \\
\hline
\end{tabular}


Berdasarkan Tabel 1, mayoritas responden berjenis kelamin perempuan. Hasil penelitian ini serupa dengan hasil penelitian Pulu (2012), yang menyatakan bahwa status karies pada siswa perempuan juga lebih tinggi dari laki-laki. Hasil penelitian serupa yang dilakukan oleh Berwulo (2011) dan Sihombing (2009) menunjukkan indeks DMF-T lebih banyak dimiliki oleh anak perempuan dibandingkan dengan anak laki-laki. Selama masa kanak-kanak dan remaja, perempuan menunjukkan nilai indeks karies lebih tinggi dari laki-laki. Mayoritas Siswa MI yang mengalami karies adalah usia 10 dan 11 tahun (Sihombing, 2009; Berwulo, 2012). Hal ini serupa dengan hasil penelitian Worotitjan, Mintjelungan, dan Gunawan (2013), bahwa siswa usia sekolah dasar dengan karies gigi terjadi paling banyak pada usia 10-11 tahun.

Status karies subjek pada penelitian ini cenderung masuk dalam kategori tinggi yaitu sebesar 58,3\%. Karies gigi dalam penelitian ini yaitu karies pada anak MI yang dinyatakan melalui perhitungan menggunakan indeks DMF-T. Indeks DMF-T adalah angka yang menyatakan adanya karies gigi (decayed), kehilangan gigi (missing) dan tumpatan (filling) pada seluruh gigi permanen. Rerata DMF-T adalah jumlah seluruh nilai DMF dibagi atas jumlah orang yang diperiksa. Rerata indeks DMF-T Siswa MI adalah 4,9, nilai ini tergolong tinggi.

Prevalensi karies yang tinggi pada anak-anak usia sekolah lebih disebabkan oleh sering mengonsumsi makanan yang mengandung karbohidrat, terutama karbohidrat sederhana seperti permen, coklat manis dan crackers (Abbass et al., 2019). Selain itu, anak sekolah juga lebih suka mengonsumsi minuman yang mengandung pemanis atau jus buah dengan kandungan gula yang cukup tinggi. Hal tersebut menjadi faktor yang berhubungan dengan kejadian karies gigi (Sanders et al., 2020). Namun, bahan makanan tinggi kalori dan karbohidrat belum tentu menyebabkan karies gigi. Makanan yang kenyal seperti permen karet dan marshmallow, meskipun mengandung kadar gula tinggi, merangsang produksi air liur dan memiliki sifat kariogenik yang lebih rendah. Sifat kariogenik suatu bahan makanan dapat dipengaruhi oleh volume dan kualitas air liur; konsistensi, dan komposisi nutrisi dari makanan yang dimakan; penumpukan plak gigi; dan kecenderungan genetik untuk membusuk. Bentuk dan konsistensi makanan memiliki efek signifikan pada potensi kariogeniknya dan kapasitas penurun $\mathrm{pH}$ atau buffering. Bentuk makanan menentukan durasi paparan atau waktu retensi makanan di mulut, yang pada gilirannya mempengaruhi berapa lama penurunan $\mathrm{pH}$ atau aktivitas penghasil asam akan bertahan (Mahan and Raymond, 2017). Karies gigi sendiri dapat menyebabkan gangguan pertumbuhan pada anak seperti status gizi kurang dan stunting (DimaisipNabuab et al., 2018).

Tabel 2 dan 3 menunjukkan bahwa terdapat hubungan yang signifikan antara asupan kalsium dan fosfor terhadap karies gigi anak sekolah MI. Hal ini sejalan 
dengan penelitian sebelumnya yang menyatakan bahwa ada hubungan signifikan antara asupan kalsium dan fosfor dengan karies gigi anak sekolah (Lin HS et al., 2014). Hasil ini juga didukung oleh Hendarto (2015) yang menyatakan bahwa kalsium dan fosfor berpengaruh terhadap kekuatan jaringan dental dan melindungi gigi agar terhindar dari karies gigi pada anak sekolah. Anak sekolah dengan kadar mineral kalsium dan fosfor pada gigi yang lebih tinggi cenderung berisiko lebih rendah mengalami karies gigi (Hartami, Irmawati and Herawati, 2019). Kekurangan mineral kalsium dan fosfor dapat berakibat terjadinya hipoplasia enamel dan meningkatkan resiko karies gigi (Hendarto, 2015). Makanan sumber kalsium dan fosfor seperti produk susu akan membantu melindungi $\mathrm{pH}$ asam yang dihasilkan oleh makanan kariogenik, sehingga berpotensi mencegah terjadinya karies gigi (Ravishankar et al., 2012). Hasil penelitian ini berbeda dengan penelitian Meikawati (2005) yang menyatakan bahwa tiak ada hubungan antara asupan kalsium dan fosfor pada ada sekolah (Meikawati, Sayono and Nurullita, 2005). Perbedaan ini dapat terjadi karena perbedaan metode pengumpulan data asupan, dimana penelitian tersebut menggunakan metode recall $3 \times 24$ jam. Perbedaan teknis pengumpulan data asupan makanan diduga memberikan gambaran pola data asupan yang berbeda (Meikawati, Sayono and Nurullita, 2005).

Gigi berlubang disebabkan oleh demineralisasi email gigi oleh asam, seperti laktat dan asetat, yang terbentuk dari makanan kariogenik seperti fermentasi gula dan pati oleh bakteri plak gigi. Susu atau produk dairy yang mengandung banyak kalsium dan fosfor memiliki sifat antikariogenik sehingga dapat mengurangi kelarutan email, meningkatkan remineralisasi, dan mencegah adhesi streptococcus mutans ke permukaan gigi (Mahan and Raymond, 2017). Dalam kaitannya dengan hubungan antara asupan mineral makanan dan penyakit mulut, konsentrasi kalsium (Ca) dan fosfor (P) dari plak gigi dan kadar ion $\mathrm{Ca}$ dan $\mathrm{P}$ dalam saliva dapat mempengaruhi keseimbangan antara demineralisasi dan remineralisasi email (Yoshihara A et al., 2009).

Tabel 2 Hubungan asupan kalsium dengan karies gigi

\begin{tabular}{|c|c|c|c|c|c|c|c|}
\hline \multirow{3}{*}{ Kategori } & \multicolumn{7}{|c|}{ Kategori DMF-T } \\
\hline & \multicolumn{2}{|c|}{ Rendah } & \multicolumn{2}{|c|}{ Sedang } & \multicolumn{2}{|c|}{ Tinggi } & \multirow[t]{2}{*}{ Nilai $p$} \\
\hline & $\mathrm{n}$ & $\%$ & $\mathbf{n}$ & $\%$ & $\mathbf{n}$ & $\%$ & \\
\hline Kurang & 11 & 14,9 . & 21 & 28,4 & 42 & 56,8 & $0,031 *$ \\
\hline Cukup & 2 & 9,1 & 6 & 27,3 & 14 & 63,6 & \\
\hline
\end{tabular}


Tabel 3. Hubungan asupan fosfor dengan karies gigi

\begin{tabular}{|c|c|c|c|c|c|c|c|}
\hline \multirow{3}{*}{ Kategori } & & & \multicolumn{4}{|c|}{ Kategori DMF-T } & \multirow{3}{*}{ Nilai $p$} \\
\hline & \multicolumn{2}{|c|}{ Rendah } & \multicolumn{2}{|c|}{ Sedang } & \multicolumn{2}{|c|}{ Tinggi } & \\
\hline & $\mathrm{n}$ & $\%$ & $\mathbf{n}$ & $\%$ & $\mathrm{n}$ & $\%$ & \\
\hline Kurang & 9 & 15,8 & 20 & 35,1 & 28 & 49,1 & $0,029 *$ \\
\hline Cukup & 4 & 10,3 & 7 & 17,9 & 28 & 71,8 & \\
\hline
\end{tabular}

Penelitian ini memiliki kelemahan diantaranya yaitu penelitian ini menggunakan desain cross sectional, sehingga belum dapat menganalisis kausalitas bahwa asupan fosfor dan kalsium menjadi penyebab karies gigi anak sekolah. Selain itu, penelitian ini hanya fokus pada asupan 2 jenis mikronutrien, dan tidak menganalisis faktor lain. Penelitian ini dapat dikembangkan lebih lanjut, terutama terkait desain penelitiannya dan analisis variable lain terkait karies gigi.

Pola makan memiliki efek lokal pada integritas gigi; jenis, bentuk, dan frekuensi makanan dan minuman yang dikonsumsi memiliki efek langsung pada pH oral dan aktivitas mikroba, yang dapat menyebabkan kerusakan gigi. Zat gizi secara sistemik mempengaruhi perkembangan, pemeliharaan, dan perbaikan gigi dan jaringan mulut (Mahan and Raymond, 2017). Asupan gizi dari diet mempengaruhi rongga mulut, begitupun sebaliknya, status rongga mulut dapat memengaruhi kemampuan seseorang untuk mengkonsumsi makanan yang memadai dan mencapai keseimbangan asupan dan kebutuhan gizi (Touger-Decker and Mobley, 2013). Berbagai faktor lain yang menjadi penyebab karies gigi pada anak sekolah yaitu mengkonsumsi minuman yang mengandung pemanis, diet vegetarian, status gizi, dan defisiensi beberapa vitamin dan mineral juga mendorong terjadinya karies pada gigi seperti defisiensi vitamin A, B, C, dan D, fluor dan zinc ((Sanders et al., 2020; Smits, Listl and Jevdjevic, 2020; Swaminathan et al., 2019; Ramayanti and Purnakarya, 2013)).

\section{KESIMPULAN}

Kalsium dan fosfor berhubungan signifikan terhadap kejadian karies gigi pada anak sekolah MI. Setelah mengetahui hasil ini, diharap pendidik dan pengelola MI untuk dapat memberikan edukasi terkait peran kalsium dan fosfor terhadap kejadian karies gigi untuk mengurangi kejadian karies gigi pada anak sekolah.

\section{UCAPAN TERIMA KASIH}

Ucapan terima kasih saya haturkan kepada Ditjen Penguatan Riset dan Pengembangan Kementerian Riset, Teknologi, dan Pendidikan Tinggi selaku pemberi Hibah Penelitian ini. 


\section{DAFTAR PUSTAKA}

Abbass, M. M. S. et al. (2019) 'The prevalence of dental caries among egyptian children and adolescences and its association with age, socioeconomic status, dietary habits and other risk factors. A cross-sectional study [version 1; referees: 1 approved, 2 approved with reservations]', F1000Research, 8, pp. 119. doi: 10.12688/f1000research.17047.1.

Bener, A. et al. (2013) 'The impact of dietary and lifestyle factors on the risk of dental caries among young children in Qatar', Journal of the Egyptian Public Health Association, 88(2), pp. 67-73. doi: 10.1097/01.EPX.0000430962.70261.8e.

Berwulo, H. (2012) Gambaran tingkat karies berdasarkan status kebersiban gigi dan mulut pada siswa sekolah dasar di Desa Ranowangko II Kecamatan Kombi. Universitas Sam Ratulangi.

Collins, W., Walsh, T. and Figures, K. (1999) A bandbook for dental bygienist. 4th edn. Oxford: Butterworth-Heinemann.

Dimaisip-Nabuab, J. et al. (2018) 'Nutritional status, dental caries and tooth eruption in children: A longitudinal study in Cambodia, Indonesia and Lao PDR 11 Medical and Health Sciences 1117 Public Health and Health Services 11 Medical and Health Sciences 1105 Dentistry', BMC Pediatrics. BMC Pediatrics, 18(1), pp. 1-11. doi: 10.1186/s12887-018-1277-6.

Fleming, E. and Afful, J. (2018) 'Prevalence of total and untreated dental caries among youth: United States, 2015-2016', NCHS data brief, (307), pp. 1-8.

Hartami, E., Irmawati and Herawati (2019) 'Perbedaan Kadar Kalsium dan Fosfor Gigi Sulung pada Anak dengan DEF-T Rendah dan Tinggi', E-Prodenta Journal of Dentistry, 3(2), pp. 232-239.

Hendarto, A. (2015) 'Nutrisi dan kesehatan gigi-mulut pada anak', Sari Pediatri, 17(1), pp. 71-75. doi: 10.14238/sp17.1.2015.71-5.

Kemenkes (2017) Tabel Komposisi Pangan Indonesia 2017.

Kemenkes RI (2013) Angka kecukupan gizi energi, protein, lemak, mineral dan vitamin yang di anjurkan bagi bangsa Indonesia. Lampiran Peraturan Menteri Kesebatan Republik Indonesia Nomor 75 Tabun 2013.

Kementrian Kesehatan RI (2018) Bahan ajar keperawatan gizi: Pelayanan asuban kesehatan gizi dan mulut masyarakat.

Kementrian Kesehatan RI (2019) Peraturan menteri kesehatan Republik Indonesia nomor 28 tahun 2019 tentang angka kecukupan gizi yang dianjurkan untuk masyarakat Indonesia.

Lin HS et al. (2014) 'ssociation of dietary calcium, phosphorus, and magnesium intake with caries status among schoolchildren', Kaohsiung J Med Sci, 4. doi: 10.1016/j.kjms.2013.12.002.

Mahan, L. K. and Raymond, J. L. (2017) Krause's food \& the nutrition care process. 14th edn. Canada: Elsevier.

Meikawati, W., Sayono and Nurullita, U. (2005) 'Hubungan konsumsi kalsium dalam makanan dan minuman dengan keparahan karies gigi pada murid kelas Iv dan V, SDN Mlati Kidul 1 dan 2 Kudus', Jurnal Litbang Universitas Muhammadiya Semarang, pp. 15-21. 
Pulu, M. (2012) Gambaran karies, kebersihan mulut dan kebiasaan menyikat gigi pada murid SD GMIM 21 Eben Haezer Kombos. Universitas Sam Ratulangi.

Ramayanti, S. and Purnakarya, I. (2013) 'Peran Makanan terhadap Kejadian Karies Gigi', Jurnal Kesehatan Masyarakat, 7(2), pp. 89-93.

Ravishankar, T. L. et al. (2012) 'Effect of consuming different dairy products on calcium, phosphorus and $\mathrm{pH}$ levels of human dental plaque: A comparative study', Eur Arch Paediatr Dent, 13(3), pp. 144-148. doi: 10.1007/BF03262861.

Sanders, A. et al. (2020) 'Diet quality and dental caries in the Hispanic Community Health Study/Study of Latinos', J Public Health Dent, 18(1), pp. 12-19. doi: 10.1111/jphd.12358.Diet.

Shita, A. D. P. and Sulistiyani (2010) 'Pengaruh Kalsium Terhadap Tumbuh Kembang Gigi Geligi Anak', Stomatognatic (J.K.G. Unej), 7(3), pp. 40-44.

Sihombing, J. (2009) Karakteristik penderita karies yang berobat di RSU Dr. Pirngadi Medan. Universitas Sumatera Utara.

Smits, K. P. J., Listl, S. and Jevdjevic, M. (2020) 'Vegetarian diet and its possible influence on dental health: A systematic literature review', Community Dentistry and Oral Epidemiology, 48(1), pp. 7-13. doi: 10.1111/cdoe.12498.

Swaminathan, K. et al. (2019) 'Correlation Between Body Mass Index and Dental Caries Among Three- to 12-Year-Old Schoolchildren in India: A CrossSectional Study', Cureus, 11(8). doi: 10.7759/cureus.5421.

Touger-Decker, R. and Mobley, C. (2013) 'Position of the academy of nutrition and dietetics: Oral health and nutrition', Journal of the Academy of Nutrition and Dietetics, 113(5), pp. 693-701. doi: 10.1016/j.jand.2013.03.001.

Worotitjan, I., Mintjelungan, C. N. and Gunawan, P. (2013) 'Pengalaman karies gigi serta pola makan dan minum pada anak sekolah dasar di desa Kiawa kecamatan Kawangkoan Utara', e-GIGI, 1(1), pp. 59-68. doi: 10.35790/eg.1.1.2013.1931.

Yoshihara A et al. (2009) 'longitudinal study of the relationship between diet intake and dental caries and periodontal disease in elderly Japanese subjects. Gerodontology', Gerodontology, (2). doi: 10.1111/j.1741-2358.2008.00244.x. 
Halaman ini sengaja dikosongkan. 